\title{
Unipolar World in Crisis as Russia Challenges US and Allies, Dragging Other Disgruntled Countries Along
}

\author{
Fatai Ayisa Olasupo \\ Department of Local Government Studies, Faculty of Administration, Obafemi Awolowo University, \\ Ile-Ife, Nigeria \\ Email: faolasupo@yahoo.com
}

Received 17 January 2014; revised 17 February 2014; accepted 24 February 2014

Copyright (C) 2014 by author and Scientific Research Publishing Inc.

This work is licensed under the Creative Commons Attribution International License (CC BY).

http://creativecommons.org/licenses/by/4.0/

c) (i) Open Access

\begin{abstract}
For more than two decades after the collapse of Soviet Union and concomitantly, cold war, United States of America became dominant world power, with western powers queuing behind her. Preoccupied by domestic political and economic problems that led, in the first instance, to the collapse of the octopus (Soviet empire), the old rival and foe receded from international politics and other engagements. United States and her western allies, thus, had field days in most part of Europe, South America, Asia, Middle East and Africa. However, having gathered sufficient political and economic stability, Russia, in the last one year, is not only making foray into international politics but actually challenging US socially, politically and militarily. This paper is out to examine how Russia is doing these dragging along some disgruntled continents against United States of America and her allies.
\end{abstract}

\section{Keywords}

Unipolar World; Nuclear; Chemical; Weapons; Human Rights; Religious Rights and Protests

\section{Introduction}

Today, United State of America is roundly criticized, not least within US itself, for the self-imposed duty of global police. But US is in fact and indeed eminently qualified to play this role whether anybody, any nation or any continent likes it or not. Regretting the role Albert Einstein played in the development of atomic and nuclear bombs, which might be weapons that would destroy the world should every Tom, Dick and Harry possess it, he recommended, "After World War II", for "Allied to set up a world government to control the atom bomb" (Golden, 1999; Renn, 2005). Though he argued for possession of it (by few, and across ideological divide and as 
a sort of check and balances) as a necessary step to "intimidate human race into bringing order into its international affairs, which without the pressure of fear, it would not do” (Philippe, 1999). United States of America, being the first nation in the universe to develop and use atomic bomb and seeing its devastating effect, is therefore eminently qualified to be the patent global police of atomic and nuclear weapons development and deployment.

Towards further stability of mankind, nature has raised Russia to serve as effective military counterweight to US who out of monopoly of these could become a global tyrant. Although pockets of nations in the world today, especially the developed nations, possess one form of atomic weapon or the other, US and Russia remain the undisputed superpowers, militarily.

Economically, America and her western allies are most economically endowed nations in the world. They control world economy, finance as well as corporate media houses such as CNN and BBC (Browne, 2013a). But of late, China, an ally of Russia, is challenging US domination of world economy.

If, militarily and economically, United States is the most powerful nation in the world, it of course should be the patent global police force. This kind of leadership cannot be elected or appointed. It is a personal quality of a nation. However, most nations in the world, and indeed, continents, are not comfortable with the way that America exercises these powers. Issues over, which United States of America and its allies clash with the rest of the world ranges from nuclear power, chemical weapons (any weapon of mass destruction), Democracy, Human rights violation, and Religion. They recently added another issue of gay and lesbian rights, which Russia and most Africans and Arab countries kicked against.

The concern of this paper is to examine how America and her allies are being challenged by other countervailing powers such as Russia and China in particular as well as some disgruntled nations opposed to America and her allies' despotism with regards to monopolization of military and economic powers.

\section{Nuclear Power}

Since after the First and Second World Wars, the dichotomy between the West and the East has deepened in World affairs, not necessarily military but also economically, ideologically and socially, particularly between United State of America and Russia, the inheritor of Soviet arsenal of nuclear weapons. US and her Western nations are the richest group in the world while Russia-China and their other allies are the more populous group (Browne, 2013a). While America and her allies are always quick to deploy military action, Russia and her allies often prefer peaceful means that, in US and her allies view, slow down actions and waste a lot of time and resources. Ultimately, Russian and her allies approach always triumph though in the face of perceived real military threat by US and her allies. Cuban missiles crisis of 1961, North Korean missiles of April 2013 and the current Syria chemical weapons of 2013 are clear examples of triumph of diplomacy over militocracy.

Nations with nuclear power ambitions to which US and her allies are opposed to include North Korea and Iran. Although the two nations have been dragged to the United Nations by US and her allies, the Security Council of the United Nations has never spoken with one voice. While US and her allies (Britain and France) at the Security Council favor military action against the two countries, Russia and her ally, China, opposed it. The failure of this led US and her ally to impose the second weapon, economic sanction. Russia and China seem not to have effective response to this. Thus, for a very long time, the sanction appears, lately, to be taking its toll on, first Iran, and slowly on North Korea. While Iran is currently at United Nation annual general assembly pleading to be absorbed back into the world economy, South Korea is yet to budge. However, there is a new development recently in China, urging South Korea to end nuclear programs (Kate \& Yoon, 2013). Economic sanction as a means of enforcing compliance with international standard by unipolar world and her ally is, no doubt, potentate but slow in bring about the desired result. Cold war between the west and the east, and the apartheid regime in South Africa were also brought down by this economic weapon after decades of resistance.

Nuclear power, since after the Word War II, has never been used as a means of settling international dispute, not because it is not effective in doing so but because of its over-devastating effect; and more importantly, its proliferation across regions of the world on ideological basis that began after the Second World War. But it has always been used as a means of check and balances between the west and the east, led by US and Russia respectively. Its use by any nation today could trigger off the First World Nuclear War, given its proliferation across the world (See Figure 1).

A study of the world nuclear map above reveals "There are eight sovereign states that have successfully detonated nuclear weapons. Five are considered to be "nuclear-weapon states" (NWS) under the terms of the 


\section{List of states with nuclear weapons}

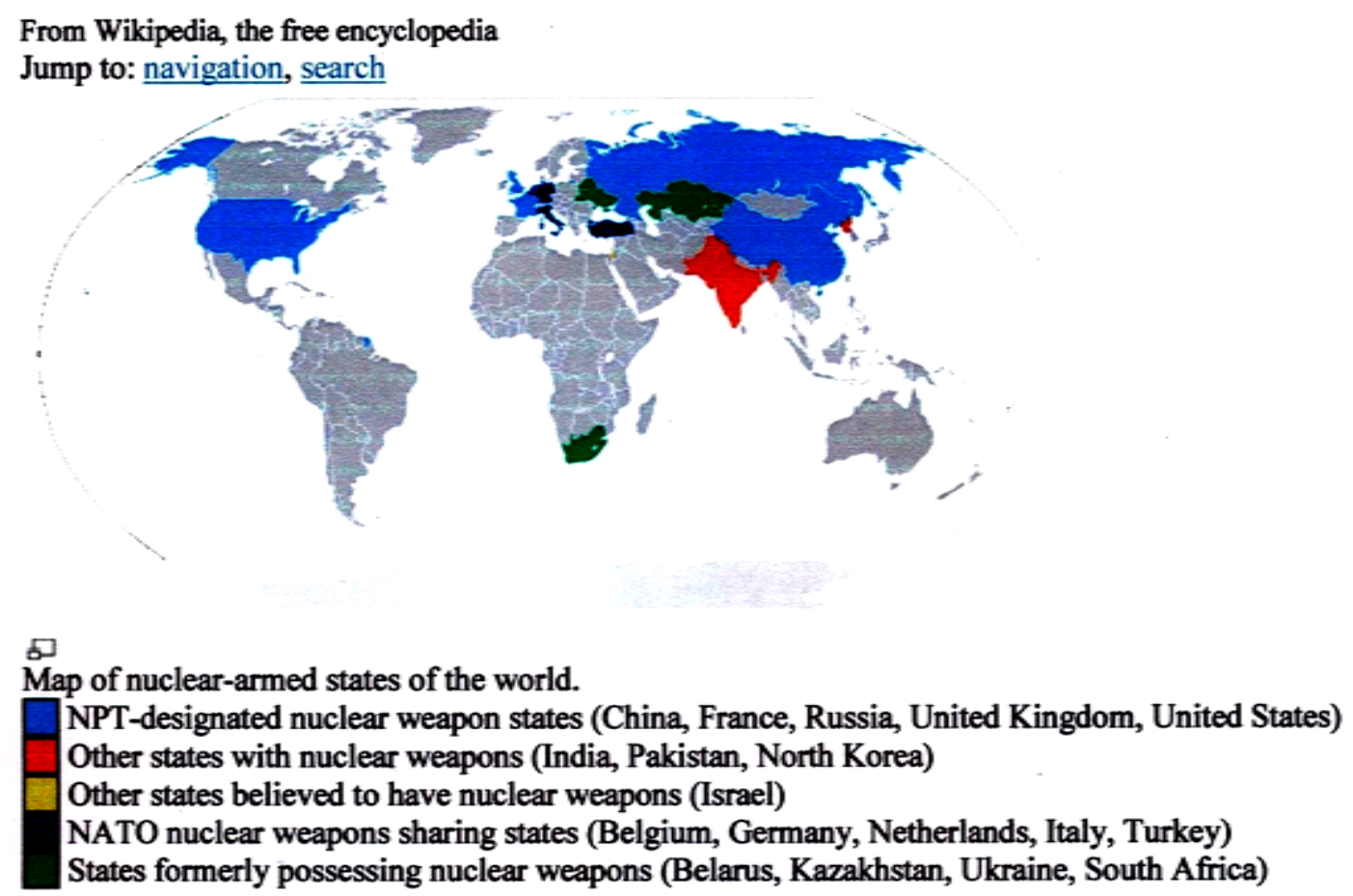

\section{South Africa has the unique status of a nation that developed nuclear weapons but has since disassembled its arsenal before joining the NPT.}

Figure 1. List of States with nuclear weapons.

Nuclear Non-Proliferation Treaty (NPT). In order of acquisition of nuclear weapons these are: the United States, Russia (successor to the Soviet Union), the United Kingdom, France, and China. These Nations that are known to possess nuclear weapons are sometimes referred to as the nuclear club.

Since the NPT entered into force in 1970, three states that were not parties to the Treaty have conducted nuclear tests, namely India, Pakistan, and North Korea. North Korea had been a party to the NPT but withdrew in 2003. Israel is also widely believed to have nuclear weapons, though it maintains a policy of deliberate ambiguity regarding this, and is not known definitively to have conducted a nuclear test.

South Africa has the unique status of a nation that developed nuclear weapons but has since disassembled its arsenal before joining the NPT” (Wikipedia, 2013).

The detonation of atomic bomb in Heroshima and Nagasaki during the World War II establishes the pre-eminence of United States of America in nuclear power not only by being the first nation in the world to develop, produce and deploy it but also by the fact that she has the largest number of allies with nuclear powers: western Europe, India, Pakistan and South Africa (before the collapse of Apartheid system). Her closest rival, Russia, has just China and North Korea. All these nuclear weapons are located across four continents of North America, Europe, Asia and Africa (But Africa is no longer in contention). Nuclear weapon deployment in Asia observes the traditional dichotomy and balance associated with US-Russia dichotomy. While Russia has nuclear weapons allies in two Asian States (China and South Korea), United States also have two nuclear weapons allies in the same Asian States of India and Pakistan (highly close neighbors; in fact Pakistan was part of India when the later was under British rule). However, while China is the mentor of North Korea, which receives instructions from her (China) the two allies of US though also receive instructions from US; constantly bicker, particularly over ownership of Kashmir. The two Asia nuclear nations, under the influence of US are due to meet in New York (their nuclear headquarter) any moment from now (BBC News, 2013a). The situation in this part of Asia is a global albatross, regardless of whether it is in the sphere of US or Russian. 
Middle East, another flash point of the world, and currently the focus of unipolar world for its terrorist activities and religious fundamentalism, is also under watch for potential nuclear weapon possession. Although there is no pragmatic evidence that Israel is a nuclear power nation, it is highly believed she possesses one. Recently, Federation of American Scientists estimates that she "has about 80 atomic weapons", which she (Israel) has always declined to confirm (Karimi, 2013). However, three reasons account for this suspicion. One, her closeness to United States is too intimidating not only to the Arab world but other Israeli enemies worldwide. Two, if Jewish scientists had not been forced out of Germany, Germany would have been the first country in the world to produce atomic bomb. In other words, if United States had not granted Albert Einstein and his persecuted fellow Jewish scientists' emigration from Germany, and allow them to acquire American citizenship in 1939 when World War II was looming, US would not have become the first producer of atomic bomb. The Jews are therefore the gadfly of atomic weapons development. When the State of Israel was established in 1948, shortly after World War II; the doyen of atomic weapon-Albert Einstein-Israel was offered the presidency of the new State of Israel, though he turned it down. His reason for the rejection was that, for him, "Politics is for the moment while... an equation is for eternity" (Hawking, 1999).

Above all, the two most powerful and pervasive religions in the world (Islam and Christianity) affirm the supremacy of Jews as the God's chosen race. Not only are Arabs and Jews product of the same region-Middle East - they also have the same paternal origin; hence a lot of similarities in both Quran and Bible (See Table 1). Israel as a nation is recognized in the Holy Quran ("Yabaniiisraila" that is Oh children of Israel) appears in the following chapters 2:40; 2:47 and 2:122). However, the Jews never adopted any of these two global religions. Even though Christ is a Jew, he is never seen as their-own Messiah and so Judaism is their adopted state religion (See Table 1). Given this backdrop, it is illogical not to expect that Jewish scientists all over the world would not have fortified their ancestral home with nuclear might.

Thirdly and finally, Hebrew University in Jerusalem is the inheritor and "guardian of his" (Albert Einstein's) "archives which are deposited in Jerusalem" (Magidor, 2005). If a Jew is behind the discovery of Atomic Bomb which powerful nations in the world today are striving to acquire, then why not Jewish nation that has suffered immensely, firstly within their Arab neighbors and, secondly, in Diaspora, especially in Germany? (Renn, 2005). Listen to the Israeli Prime Minister, Benjamin Natanyahu's speech at the just concluded 2013 UN general assembly: "Israel will not allow Iran to get nuclear weapon. If Israel is forced to stand alone, Israel will stand alone. Yet, in standing alone, Israel will know that we will be defending many, many others” (The Times of Israel, 2013). Could this be a declaration from a nuclear power free nation?

The Islamic world that became unstable with the founding of the State of Israel in 1948 are searching for nuclear parity with Israel and found one in Iran. Like Israel whose nuclear possession is shrouded in mystery, Iran's nuclear ambition is equally shrouded in mystery. While the whole world, especially US and Israel, believe Iran is close to development of nuclear weapon, Iran continuously denies this; claiming that its nuclear program is for peaceful use only. After more than a decade of relentless economic sanction against Iran by US and her western allies, Iran has finally being brought down on her knees. As a proof that Iran is serious for her nuclear program negotiation with the Unipolar world, "The US and China have said they expect Iran to respond to an existing offer by the US, Russia, Britain, France, China and Germany, who form a negotiating group known as the $5+1$ " (Germany being the +1 ). Russia is however not comfortable with the dominating influence of US in the Middle East. She demonstrated this recently with the Syrian issue. We shall come back to this later (BBC News, 2013b).

Attention now focuses on North Korea who is also under heavyweight of western allies economic sanctions. To start with, Kaesong industrial zone which was closed down early last year by North Korea because of US outcry over her (North Korea) testing of long range missile has been reopened. It is believed in some quarters that shortage of needed hard currency forced her to reopen it. Shortly after, her mentor, China, added her own pressure on North Korea. "The Chinese leader, Xi Jin ping", it is reported, "bluntly told a North Korean envoy on Friday that his country should return to diplomatic talks intended to ride it of its nuclear weapons" (Perlez, 2013a). As economic, military and nuclear benefactor of North Korea, China recently "published a long list of equipment and chemical substances to be banned from export to North Korea for fear they could be used in adding to its increasingly sophisticated nuclear weapons programs” (Perlez, 2013b). With North Korea being increasingly isolated by China, her mentor and ally, it is a question of time before she appears before United Nations like her heady but subdued colleague-Iran. Prime Minister Benjamin Netanyahu of Israel, while delivery his speech at last year's UN general assembly attested that "North Korea, agreed in principle this week to dis- 
Table 1. Jesus in the Quran.

\begin{tabular}{|c|c|}
\hline TITLES & QUR'AN \\
\hline 1. A word from God, His (God’s) word (Kalimah) & 3:34/39, 40: 169/171 John 1:1; 14 \\
\hline 2. A word of Truth (Qawl Al-haqq) & 19:35/34 John 8: 32-36; Ephesians 1:13. \\
\hline 3. The Truth from your Lord (Al-haqq) & 3:53/60 John 8:32 - 36, 14:6. \\
\hline 4. A spirit from God (Ruth) & 4: 169/171; 19: 17; 21:91 Matt. 12:28, Luke 1:35. \\
\hline 5. The Messiah (al-Masih) & 3:40/45; 4:156/157. Matt. 16:16; John 1:41. \\
\hline 6. Apostle (Messenger) (Rasul) & 2:81/87, 254/243; 3: 43/49. Hebrews 3:1, Matt. 10:40. \\
\hline 7. Prophet (Nabiyy) & 2:130/136; 4:161/163att. 21:11, Luke 4:24. \\
\hline 8. Servant of God ('Abd Allah). & 4:170/172; 19:31/30, Matt. 12:18, John 4:34. \\
\hline 9. Son of Mary (Ibn Maryam). & 3:40/45; 4:157; 171 Luke 2:48. \\
\hline 10. Witness on Resurrection Day (shahid) & 4:45/41; 4:157; 171 Luke 2:48. \\
\hline 11. Witness of (over) The people & 5:120/117. John 5:30. \\
\hline 12. Mercy from us (God) (Rahmah). & 19:21; Matthew 9:27 - 30. \\
\hline 13. Bearer of wisdom (Hikmah). & 43:63; Luke 2:40, 52. \\
\hline 14. Knowledge of the hour (Cllm) & 43:61; Matthew 24:36 - 44; John 4:25. \\
\hline 15. Sign to all beings (Ayah). & 3:44/50; 19:21; 21:91; Matthew 2:2; 29. \\
\hline 16. Sign of the hour (Judgement Day) & 23:50. Matthew 24:37 - 38, Acts 1:11. \\
\hline 17. The Miracle Worker. & 3:49; Mark 1:34; 5:41 - 42: 6:53. \\
\hline 18. Revelation to mankind (Ayah) & 19:21. Luke 2:10; 30 - 32. \\
\hline 19. The one to be followed & 43:61. John 1:37; John 10:27. \\
\hline 20. The one to be obeyed & 3:44/50. Matt. 17:5; 8:27, Mark 1:27. \\
\hline 21. Giver (Bringer) of good Tidings. & 61:6. Luke 4:18; Acts 10:38. \\
\hline 22. One of the Righteous (min Salihin) & 3:40/46/ Matt. 27:19; 2 Tim. 4:8. \\
\hline 23. The Knowledge in Scriptures & 3:43/48; 5:109/110. Matt. 12:25; John 4:25. \\
\hline 24. The Like of ADAM (Mathal al Adam). & 3; 52/59. I Corinthians 15:45 - 47. \\
\hline 25. The Faultless (Holy, Most Pure) son (Zakiy). & 19:19. Luke 23:1; 14, 41; Acts 2:14. \\
\hline 26. One of the Closest to God (Min at Muqarrabin) & 3:40/41; 7:111/114 John 14:9 - 10, Hebrews 2:9 \\
\hline 27. High Honoured (EminentI in this World and Hereafter (Wajih). & 3:40/45 Philip. 2:9 - 10, Ephesians 1:21. \\
\hline 28. The Blessed one (Mubarak) & 19:32/31 Matt. 21:9; Luke 1:42. \\
\hline 29. The Favoured one. & 43:59. John 1:18; Mark 1:11. \\
\hline $\begin{array}{l}\text { 30. The one confirmed (Strengthened) } \\
\text { with the Holy Spirit (Ruh Al-qudsi) }\end{array}$ & 2:81/87, 254/253. Mark 1:11; Luke 4:14; Acts 2:33. \\
\hline 31. The Noble; Lordly (Sayyid). & 3:39. Matt 21:8 - 10. \\
\hline 32. The Chaste (Hasuwur) & 3:39. 2 Corinthians 5:21; I Peter 2:22. \\
\hline 33. A man of PEACE (Salam) & 19:34/33. Isaiah 9:6, Daniel 19:25; Acts 5:31. \\
\hline 34. A perfect Man (Sawiy) & 19:17. I Corinthians 13:10; \\
\hline
\end{tabular}

Source: Fatai Ayisa Olasupo, (2013) “The Role of Arabian and Western Civilization in Extinction of African Traditional Religion: The case studies of Senegal, South Africa and Nigeria” in International Journal of Sustainable Development, Canada: International Development Agency. Available at SSRN: http://srn.com/abstract = 2,333,260 Vol. 05, No. 12, pp. 19-34. 
mantle its nuclear weapons program, and return to the NPT, abide by the treaty's safeguards and admit international inspectors”. "And finally, diplomacy, it seems, does work after all.” (The Times of Israel, 2013).

Meanwhile, the grave situation in Korean peninsula led the South Korean President Park Geun-hye to also state that "We have to build strong deterrence against North Korea until the North Abandons its nuclear program and makes the right choice for the people of North Korea and peace on the Korean Peninsula" (BBC News, 2013c).

Accidently, USA and Russia also divided up in the ways both nearly plunged the world into nuclear war by error. The nearly self-inflicted nuclear accident took place in US in 1961 and in USSR in 1983. In the case of US "An atomic bomb nearly detonated over North Carolina in 1961. The explosive said to be 260 times more powerful than the device that hit Hiroshima, dropped on North Carolina when a B-52 plane broke up in midair on January 23, 1961. (See example of that of Hiroshima below). "Fallout from the explosion could have spread to Washington, Baltimore, Philadelphia and even New York City, affecting millions of people" (The Guardian, 2013a). If this had happened, the instant and immediate suspect would have been USSR for no nation at that time possessed such nuclear power other than these two nuclear rival powers. Nobody would have immediately believed it was an accidental discharge.

Of recent, minor incidences - three in all—that could lead to nuclear error are also recorded in US and the three led to sacking of nuclear military generals concerned. First, General Michael Cary who is in charge of the US Air Force's long-range nuclear missiles has been sacked due to "loss of trust and confidence" (BBC News, 2013d). He is in charge of Intercontinental ballistic missiles (ICBMs). Secondly, Vice Admiral Tim Glardina has been removed as second in command of US strategic command. His job was to oversee the nation's nuclear weapons. His offence borders on illegal gambling activities. "He is accused of using counterfeit gambling chips in "a significant monetary amount" at an Iowa casino" (BBC News, 2013d). Thirdly, Admiral Giardina was demoted to a two-star admiral and is being reassigned pending outcome of an inquiry. Fourthly and finally, in another public embarrassment for the Air Force's nuclear missile program, two crew members were found guilty of leaving silo blast doors open while they were on duty in an underground facility housing nuclear missiles. The punishment for the crew who was found derelict was to forfeit \$2246 in pay for each of two months, while the other crew, admitted to similar misconduct, "on few occasions" received a letter of admonishment (Starr, 2013).

All of these borders on failed safety and security inspection that was carried out in August at a nuclear missile unit at Maelstrom Air Force base in Montana. Earlier, in May, it was also reported that 17 officers in charge of maintaining nuclear missiles were sidelined over nuclear safety violations at Minot Air Force base in North Dakota. These are near-nuclear accidents of January 23, 1961 type over North Carolina (see Figure 2).

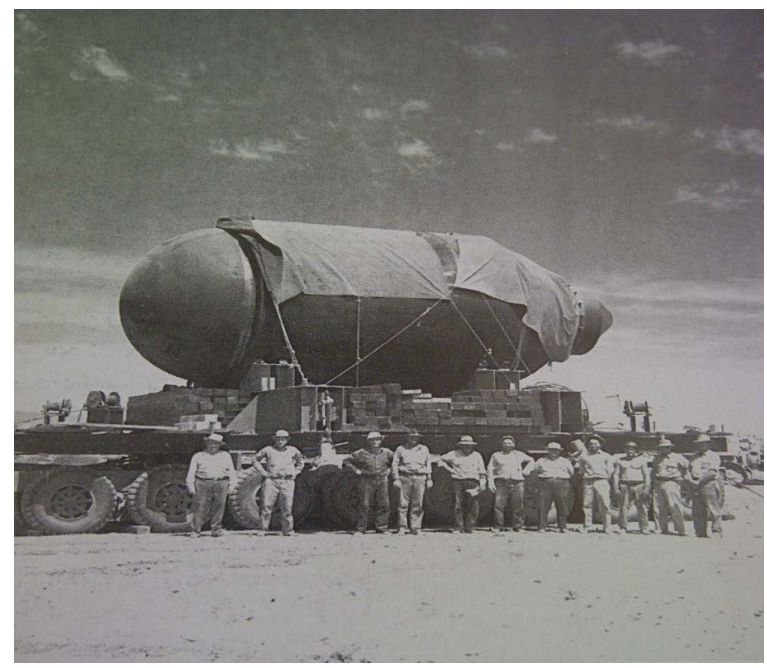

Figure 2. Preparation for the first detonation of a nuclear bomb, New Mexico, 1945. Source: JurgenRenn (Ed.) Chief Engineer of the Universe: Albert Einstein: Einstein's Life and work in context, Berlin: Weinheim and Max Plank Institute for the history of Science. P200. 
On the other hand, in USSR, three decades ago, three important incidents happened that nearly triggered off nuclear holocaust. First on the 26 November 1983, in the early morning, "the Soviet Union's early-warning systems detected an incoming missile strike from the United States. Computer readouts suggested several missiles had been launched. The protocol for the Soviet Military would have been to retaliate with nuclear attack of its own. But duty officer Stanislav Petrove whose job was to register apparent enemy missile launches decided not to report them to his superiors, and instead dismissed them as a false alarm. This was a breach of his instructions, dereliction of duty. The safe thing to do would have been to pass the responsibility on, to refer up. But this decision may have saved the world” (BBC News, 2013e). Again, if in error, Soviet Military had retaliated, nuclear war would have ensued. Americans too would have looked nowhere else for harbinger of the calamity other than USSR and, might therefore have also responded.

The second incident was a "major war game exercise, operation Able Archer, which involved 40,000 US and Nato troops moving across western Europe, co-ordinated by encrypted communications systems, imagined as scenario in which Blue Forces (Nato) defended its allies after Orange Forces (Warsaw Pact countries) sent troops into Yugoslavia following political unrest. The Orange Forces had quickly followed this up with invasions of Finland, Norway and eventually Greece. As the conflict had intensified, a conventional war had escalated into one involving chemical and nuclear weapons" (Guardian World News, 2013a).

Earlier in "September 1983, the Russia shot down a Korean Airlines Boeing 747, killing all 269 people on board, after the plane had mistakenly strayed into their airspace. There is evidence to suggest that Russians thought the Boeing was an American spy plane”.

Before these and in the same year 1983, US President Ronald Reagan, made a high-profile speech describing the Soviet Union as the "evil empire" and announced plans to build the "Star Wars" strategic defense initiative. With distrust between these two powerful nations in the world at unparalleled levels during this period, both sides “were operating on hair trigger” (Guardian World News, 2013a).

As Able Archer commenced and Russia close to threating the exercise as prelude for a nuclear strike against them (USSR), the Kremlin gave instructions for a dozen aircraft in East Germany and Poland to be fitted with nuclear weapons. In addition, around 70 SS-20 missiles were placed on heightened alert, while Soviet submarines carrying nuclear ballistic missiles were sent under the Arctic ice so that they could avoid detection. Meanwhile, Nato and its allies initially thought the Soviet response was the USSR's own form of war-gaming. These were how close the world was to nuclear disaster during the cold war.

Although the cold war is over now more than two decades ago the Director of Nuclear Information Service (NIS), an organization that campaign against nuclear proliferation, said "We continue to face unacceptable high risks and will continue to do so until we have taken steps to abolish these exceptionally dangerous weapons" because "thousands of war heads are still actively deployed by the nuclear armed states" (Guardian World News, 2013a). And not on till one of the last acts of Einstein, a week before his death is fulfilled, the world remains nuclear weapon endangered. Before Einstein's death, there was an agreement in which his name headed a manifesto urging all nations to give up nuclear weapons (Philippe, 1999).

\section{Chemical Weapon}

What began as domestic conflict two years ago in Syria has snowballed into international conflict polarizing the world into two: one led by USA and the other by Russia? The use of chemical weapon in the conflict led to the entrance of divided international community into this Syrian crisis. As in the case of nuclear bomb, this is also a weapon of mass destruction that divided the world politically, ideologically, militarily and socially. America accused Syrian government of introducing Chemical weapon into the conflict but Russia said no, Syrian rebels did. America stated that over 1400 Syrians were killed as a result of this. But, the France based medical NGO, whose doctors were on the ground, estimated the number of dead to 350 (Browne, 2013b). To stop the carnage, US wanted to enter the war militarily, but Russia countered it will also enter to defend Syrian government. US sent war ships and Russia also responded. The two antagonistic and ideological foes dragged themselves to the United Nations Security Council, where, again, the five permanent members divided up into two: USA, Britain and France to the right while Russia and China to the left. The recently concluded G-20 summit, held in Russia, also dichotomized the world into pro-US and anti-US-led by Russia (Browne, 2013a).

These dichotomies got to the head with name callings from both Russia and US using direct method of addressing their opponent's citizens through mass media of their opponents. President Vladimir V Putin was the 
first to do this using New York Times op-ed contribution to do so. According to him, "Recent events surrounding Syria have prompted me to speak directly to the American people and their political leaders. It is important to do so at time of insufficient communication between our societies".

"The potential strike by the United States against Syria, despite strong opposition from many countries and major political and religious leaders, including the pope, will result in more innocent victims and escalation, potentially spreading the conflict far beyond Syria’s borders” (Greenslade, 2013); eventually calling American Secretary of State, John Kerry “a liar”.

Responding on behalf of US, Senator McCain, the rival of President Obama in 2008 presidential campaign, chose an online Russian newspaper, Pravda, to do so. He said "Russians deserve better than Putin, he accused the Kremlin of punishing dissent, rigging elections, censoring the media and banishing political opponents. To perpetuate their power they foster rampant corruption in your courts and your economy and terrorists and even assassinate journalists who try to expose their corruption” (BBC News, 2013f).

However, the position of the US began to crumble when it began the process of shipping military weapons to Syrian coast. Her most important traditional ally, Britain, began the rebellion. The House of Common became divided on the issue and decided to put this into vote. The opposition defeated the government and the British government withdrew her military support for US, although it continued to support US diplomatically. France continued to support US position but stated that it would like her parliament to debate it. The hawk, US government, was thus also forced to ask Congress and The Senate to debate the issue of military intervention that has been stalled due to diplomatic moves that were going on.

The crack in the unity of US and her western allies was reinforced by internal cleavage within the US itself. First was the reaction of a group of American retired intelligence officers, Veteran Intelligence Officers for Sanity (VIPS). "They warned the President not to embark on war based on dubious conclusions founded on incomplete evidence". They were worried by the non-classified documents the American government published to defend its push for military action" as against the standard procedure. "The deviation", according to them "is because the American intelligence community is strongly divided on the matter" (Browne, 2013b). Their objection to military intervention is also based on the fact that a secret meeting in Turkey on August 13-14 among US allies: Israel, Saudi, Turkish, American officials as well as rebel leaders existed. At the meeting, "the rebels were told they would soon benefit from a massive influx of weapons and war materials. There was a talk of a mysterious event that would soon occur in Syria, bringing America actively into the war” (Browne, 2013b).

During the regime of President Bush that President Obama succeeded, VIPS were also said to have raised and sent a memo to him over impending military action in Iraq. The memo cautioned him against rushing to war in Iraq, which was ignored. At the end of the war neither chemical weapons were found nor were the Iraqis conquered. Ten years after the war, Iraqis are still enmeshed in internal war.

In short, international and continental oppositions are mounting towards whittling down the global power and influence of US. According to Fani-Kayode, for the first time in the world history, Russia, Iran and China will come together, finally pick up the gauntlet and muster the courage to say "no more" to American lawlessness, manipulation, deceit, double standards and butchery" (Fani-kayode, 2013). The process was about to begin when John Kerry larked at a press conference in London that "Assad could avert the military strike if he relinquished the chemical weapons. Russians seized his unguarded utterances as a basis for new approach". This forestalled American military action and led toan agreement between Russia and America: "Syria will hand over its chemical weapons and America will sheathe its sword" (Browne, 2013b). This marked the end of bickering and grandstanding on Syria matter.

The UN Security Council, capping a dramatic month of diplomacy, according to CNN, voted unanimously late Friday to require Syria to eliminate its arsenal of chemical weapons or face sanctions (See Table 2). "Today's resolution will ensure that the elimination of the Syrian chemical weapons program happens as soon as possible and with the utmost transparency and accountability, Secretary General said” (Walsh \& Labott, 2013). The UN resolution however did not authorize the automatic use of force if Syria is said to be in violation, as was previously sought by the United States (Walsh \& Labott, 2013).

\section{Charity Begins at Home}

US and Russia have also come into the focus of the world for violation of Chemical Weapon Convention. Both countries are accused of having “missed the convention's extended deadline last year to destroy all of their 
Table 2. List of countries with chemical and/or biological weapons.

\begin{tabular}{|c|c|c|c|c|c|c|c|c|}
\hline \multirow[b]{2}{*}{ Country } & \multicolumn{4}{|c|}{ Chemical } & \multicolumn{4}{|c|}{ Biological } \\
\hline & $\begin{array}{l}\text { Program } \\
\text { Status }\end{array}$ & $\begin{array}{l}\text { Possible } \\
\text { Agents }\end{array}$ & $\begin{array}{l}\text { Signed } \\
\text { CWC }\end{array}$ & $\begin{array}{l}\text { Ratified } \\
\text { CWC }\end{array}$ & $\begin{array}{l}\text { Program } \\
\text { Status }\end{array}$ & $\begin{array}{l}\text { Possible } \\
\text { Agents }\end{array}$ & $\begin{array}{l}\text { Signed } \\
\text { BWC }\end{array}$ & $\begin{array}{l}\text { Ratified } \\
\text { BWC }\end{array}$ \\
\hline Algeria & Possible & Unknown & 01/13/93 & 08/14/95 & $\begin{array}{l}\text { Research effort, but no } \\
\text { evidence of production }\end{array}$ & Unknown & - & $07 / 22 / 2001^{*}$ \\
\hline Canada & $\begin{array}{l}\text { Former pro- } \\
\text { gram }\end{array}$ & $\begin{array}{l}\text {-mustard } \\
\text {-phosgene } \\
\text {-lewisite }\end{array}$ & 01/13/93 & 09/26/95 & $\begin{array}{l}\text { Former program } \\
\text { Started: } 1941 \\
\text { Ended: } 1945\end{array}$ & $\begin{array}{c}\text { Past Weaponized } \\
\text { Agents } \\
\text {-anthrax } \\
\text { Research } \\
\text {-brucellosis } \\
\text {-rocky mountain } \\
\text { spotted fever } \\
\text {-plague } \\
\text {-tularemia } \\
\text {-typhoid } \\
\text {-yellow fever } \\
\text {-dysentery } \\
\text {-rinderpest } \\
\text {-botulinum toxin } \\
\text {-ricin }\end{array}$ & 04/10/72 & 09/18/72 \\
\hline China & Probable & Unknown & 01/13/93 & 04/25/97 & $\begin{array}{l}\text { Likely maintains an } \\
\text { offensive capability }\end{array}$ & Unknown & - & $11 / 15 / 84^{*}$ \\
\hline Cuba & Possible & Unknown & 01/13/93 & 04/29/97 & $\begin{array}{c}\text { Probable research } \\
\text { program }\end{array}$ & Unknown & 04/10/72 & $04 / 21 / 76$ \\
\hline Egypt & Probable & $\begin{array}{l}\text {-mustard } \\
\text {-phosgene } \\
\text {-sarin } \\
\text {-VX }\end{array}$ & No & No & $\begin{array}{l}\text { Likely maintains an } \\
\text { offensive program }\end{array}$ & Unknown & $10 / 04 / 72$ & No \\
\hline Ethiopia & Probable & Unknown & 01/14/93 & 05/13/96 & - & - & 04/10/72 & $05 / 26 / 75$ \\
\hline France & $\begin{array}{l}\text { Former pro- } \\
\text { gram }\end{array}$ & $\begin{array}{l}\text {-mustard } \\
\text {-phosgene }\end{array}$ & 01/13/93 & 03/02/95 & $\begin{array}{c}\text { Former program } \\
\text { Started: } 1921 \\
\text { Ended: } 1940 \\
\text { (dormant 1927-1934) } \\
\text { 1940-1945 } \\
\text { (German occupation) }\end{array}$ & $\begin{array}{c}\text { Past Weaponized } \\
\text { Agents } \\
\text {-potato beetle } \\
\text { Research } \\
\text {-anthrax } \\
\text {-salmonella } \\
\text {-cholera } \\
\text {-rinderpest } \\
\text {-botulinum toxin } \\
\text {-ricin }\end{array}$ & - & 09/27/84* \\
\hline Germany & $\begin{array}{l}\text { Former pro- } \\
\text { gram }\end{array}$ & $\begin{array}{l}\text {-phosgene } \\
\text {-hydrogen } \\
\text { cyanide } \\
\text {-mustard } \\
\text {-tabun } \\
\text {-sarin } \\
\text {-soman }\end{array}$ & 01/13/93 & 08/12/94 & $\begin{array}{c}\text { Former program } \\
\text { Started: } 1915 \\
\text { Ended: } 1945 \\
\text { (dormant 1919-1939) }\end{array}$ & $\begin{array}{c}\text { Past Weaponized } \\
\text { Agents } \\
\text {-glanders (WW 1) } \\
\text {-anthrax (WW I) } \\
\text { Research } \\
\text {-foot and mouth } \\
\text { disease } \\
\text {-plague } \\
\text {-rinderpest } \\
\text {-typhus } \\
\text {-yellow fever } \\
\text {-potato beetle } \\
\text {-potato blight }\end{array}$ & 04/10/72 & $11 / 28 / 72$ \\
\hline India & $\begin{array}{l}\text { Former pro- } \\
\text { gram }\end{array}$ & Unknown & 01/14/93 & 09/03/96 & $\begin{array}{l}\text { Research program, but no } \\
\text { evidence of } \\
\text { production }\end{array}$ & Unknown & 01/15/73 & 07/15/74 \\
\hline Iran & Known & $\begin{array}{l}\text {-mustard } \\
\text {-sarin } \\
\text {-hydrogen } \\
\text { cyanide } \\
\text {-cyanogen } \\
\text { chloride } \\
\text {-phosgene }\end{array}$ & 01/13/93 & $11 / 03 / 97$ & $\begin{array}{l}\text { Likely maintains an } \\
\text { offensive program }\end{array}$ & $\begin{array}{l}\text {-anthrax } \\
\text {-foot and mouth } \\
\text { disease } \\
\text {-botulinum toxin } \\
\text {-mycotoxins }\end{array}$ & 04/10/72 & 08/22/73 \\
\hline
\end{tabular}




\section{Continued}

\begin{tabular}{|c|c|c|c|c|c|c|c|c|}
\hline Iraq & Former program & $\begin{array}{l}\text {-mustard } \\
\text {-sarin } \\
\text {-tabun } \\
\text {-VX } \\
\text {-Agent } 15\end{array}$ & No & No & Former program & $\begin{array}{c}\text { Past Weaponized } \\
\text { Agents } \\
\text {-anthrax } \\
\text {-botulinum toxin } \\
\text {-ricin } \\
\text {-aflatoxin } \\
\text {-wheat cover smut } \\
\text { Research } \\
\text {-brucellosis } \\
\text {-hemorrhagic } \\
\text { conjuctivitis virus } \\
\text { (Enterovirus 70) } \\
\text {-rotavirus } \\
\text {-camel pox } \\
\text {-plague (?) } \\
\text {-gas gangrene toxin }\end{array}$ & $05 / 11 / 72$ & 06/19/91** \\
\hline & & Chemical & & & & Biological & & \\
\hline Country & $\begin{array}{l}\text { Program } \\
\text { Status }\end{array}$ & $\begin{array}{l}\text { Possible } \\
\text { Agents }\end{array}$ & $\begin{array}{l}\text { Signed } \\
\text { CWC }\end{array}$ & $\begin{array}{l}\text { Ratified } \\
\text { CWC }\end{array}$ & $\begin{array}{l}\text { Program } \\
\text { Status }\end{array}$ & $\begin{array}{l}\text { Possible } \\
\text { Agents }\end{array}$ & $\begin{array}{l}\text { Signed } \\
\text { BWC }\end{array}$ & $\begin{array}{c}\text { Ratified } \\
\text { BWC }\end{array}$ \\
\hline Israel & Probable & Unknown & 01/13/93 & No & $\begin{array}{l}\text { Research, with possible } \\
\text { production of agents }\end{array}$ & Unknown & No & No \\
\hline Italy & Former program & $\begin{array}{l}\text {-mustard } \\
\text {-phosgene }\end{array}$ & 01/13/93 & 12/08/95 & - & - & $04 / 10 / 72$ & $05 / 30 / 75$ \\
\hline Japan & Former program & $\begin{array}{l}\text {-phosgene } \\
\text {-hydrogen } \\
\text { cyanide } \\
\text {-mustard } \\
\text {-lewisite } \\
\text {-chloropicrin }\end{array}$ & 01/13/93 & 09/15/95 & $\begin{array}{l}\text { Former program } \\
\text { Started: } 1931 \\
\text { Ended: } 1945\end{array}$ & $\begin{array}{c}\text { Past Weaponized } \\
\text { Agents } \\
\text {-anthrax } \\
\text {-plague } \\
\text {-glanders } \\
\text {-typhoid } \\
\text {-cholera } \\
\text {-dysentery } \\
\text {-typhoid } \\
\text {-paratyphoid } \\
\text { Research } \\
\text {-gas gangrene } \\
\text {-influenza } \\
\text {-tetanus } \\
\text {-tuberculosis } \\
\text {-tularemia } \\
\text {-salmonella } \\
\text {-typhus } \\
\text {-glanders } \\
\text {-tetrodotoxin }\end{array}$ & $04 / 10 / 72$ & 06/08/82 \\
\hline Libya & $\begin{array}{l}\text { Former } \\
\text { program }\end{array}$ & $\begin{array}{l}\text {-mustard } \\
\text {-sarin } \\
\text {-tabun } \\
\text {-lewisite } \\
\text {-phosgene }\end{array}$ & - & $01 / 06 / 04^{*}$ & $\begin{array}{l}\text { Possible former program } \\
\text { Ended: } 2003\end{array}$ & Unknown & - & $01 / 19 / 82^{*}$ \\
\hline $\begin{array}{l}\text { Myanmar } \\
\text { (Burma) }\end{array}$ & Probable & & 01/14/93 & No & - & - & $04 / 10 / 72$ & No \\
\hline N. Korea & Known & $\begin{array}{l}\text {-adamsite } \\
\text {-mustard } \\
\text {-hydrogen } \\
\text { cyanide } \\
\text {-cyanogen } \\
\text { chloride } \\
\text {-phosgene } \\
\text {-sarin } \\
\text {-soman } \\
\text {-tabun } \\
\text {-VX }\end{array}$ & No & No & $\begin{array}{l}\text { Research, with possible } \\
\text { production of agents }\end{array}$ & $\begin{array}{l}\text {-anthrax } \\
\text {-plague } \\
\text {-yellow fever } \\
\text {-typhoid } \\
\text {-cholera } \\
\text {-tuberculosis } \\
\text {-typhus } \\
\text {-smallpox } \\
\text {-botulinum toxin }\end{array}$ & - & 03/13/87- \\
\hline Pakistan & Probable & Unknown & 01/13/93 & 10/28/97 & Possible & Unknown & 04/10/72 & $09 / 25 / 74$ \\
\hline
\end{tabular}




\section{Continued}

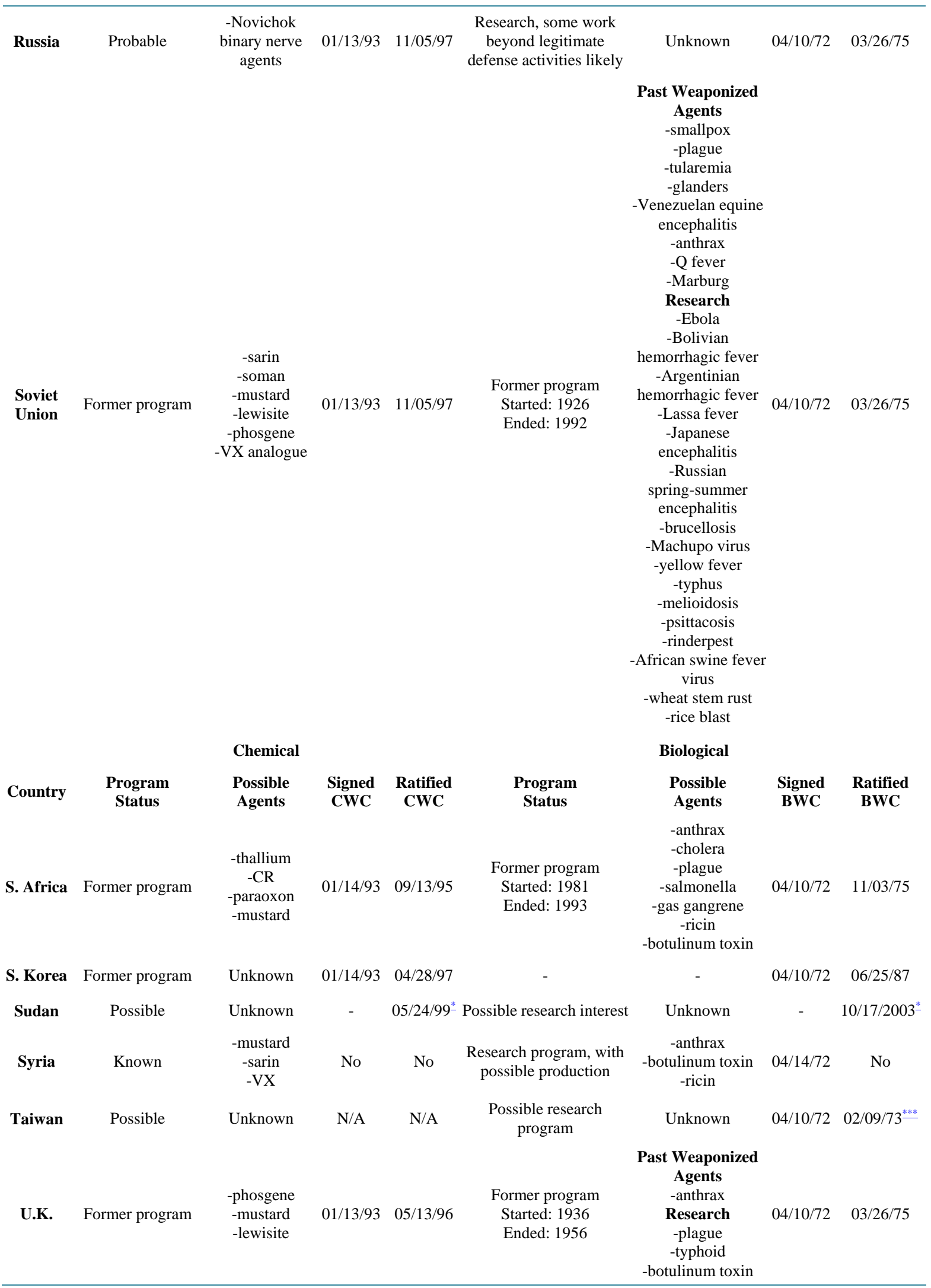




\section{Continued}

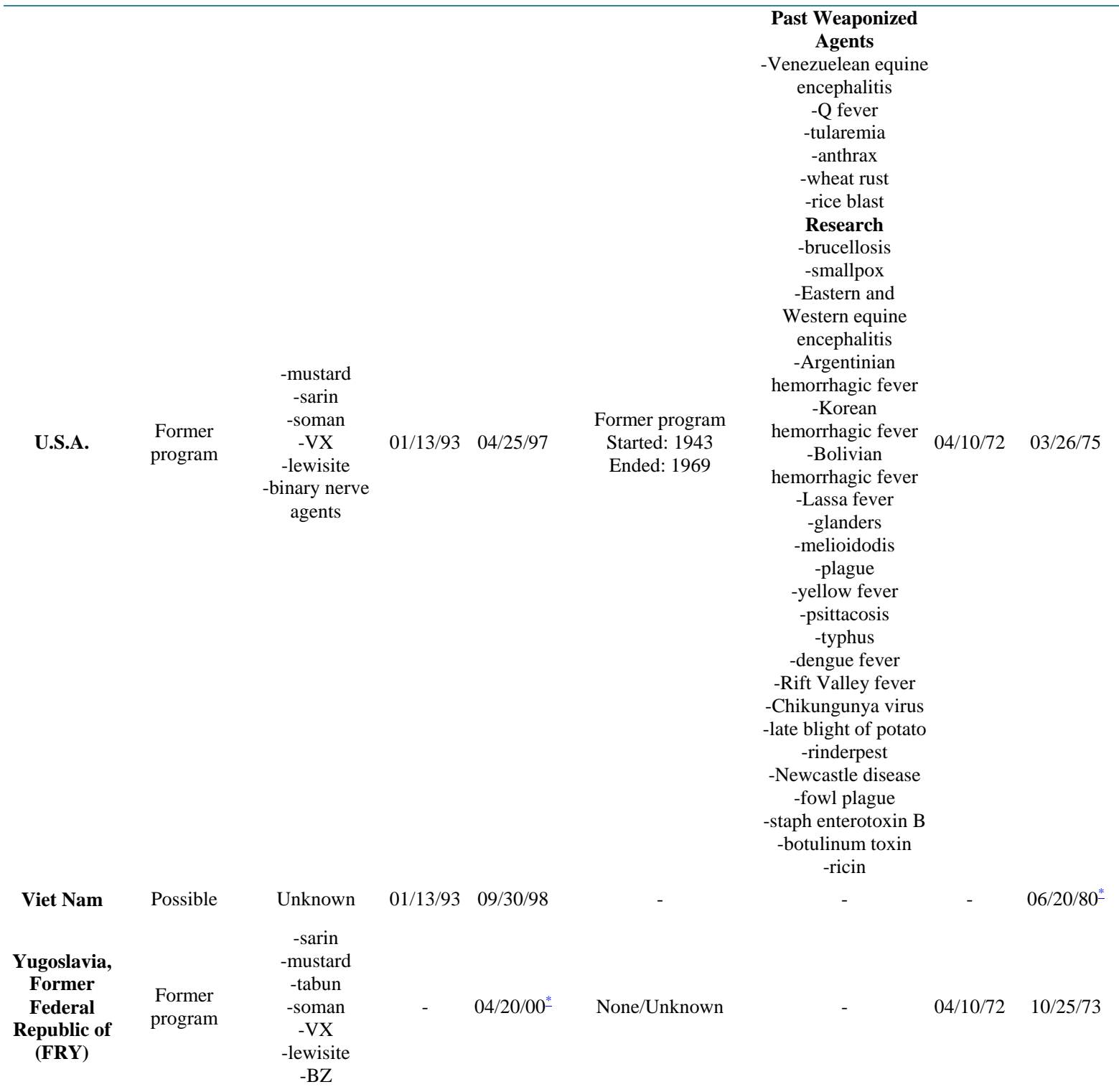

${ }^{*}$ Denotes countries which acceded to the treaty. ${ }^{* *}$ Iraq ratified the BWC following the adoption of U.N. Security Council Resolution 687 , which in addition to establishing UNSCOM, also “invited" Iraq to ratify the 1972 Convention (Paragraph 7), 04/08/91,

(http://www.un.org/Docs/scres/1991/scres91.htm). ${ }^{* * * *}$ The U.N. does not recognize Taiwan as an independent entity (from China), so their signature and ratification of the BWC in 1972, 1973 are not considered legitimate.

chemical weapons. The Nobel committee, based in Sweden, noted that "Certain states have not observed the deadline, which was April 2012, for destroying their chemical weapons. This applies especially to USA and Russia". United States responded by saying that "it will be at least another decade before it completes destruction of the remaining $10 \%$ of its chemical weapons, estimated at more than 3100 tons. Russia, said to have not even started destroying her own chemical weapons at all, has more than five times that amount left to destroy, according to the Organization for the Prohibition of Chemical Weapons (OPCW).

In recognizing the humanitarian roles of the staff of the Organization for the Prohibition of Chemical Weapon (OPCW) in Syria and it compliance with Albert Einstein's instruction before his death in 1955, the Nobel Committee in Sweden awardedit (OPCW) Nobel Peace Prize while the OPCW seized the opportunity to condemned US and Russia for noncompliance with Chemical Weapon destruction Treaty they entered into in1972. Charity begins at home. If US and Russia are violating Chemical Weapon convention they willingly acceded to, 
of what moral rights have they to compel others? To their credit however, none of them, including their allies, have ever used it in the way it was used in Syria. The abuse of its usage in Syria led to international outcry that warranted checking further use of it and indeed outright disposal of it. Albert Einstein had, before his death, instructed that "We scientist, whose tragic destination has been to help in making the methods of annihilation more gruesome and more effective, must consider it our solemn and transcendent duty to do all in our power in preventing these weapons from being used" (Rosenblatt, 1999).

To this end, he (Einstein) and Russell presented what is known as Russell-Einstein peace Manifesto in 1955. "The famous peace manifesto demanding nuclear disarmament and a stop to the development of the hydrogen bomb. Another disarmament document is also signed by eleven prominent scientists, including nine Nobel laureates". Following this was Gottingen Declaration of 1957. This declaration was against planned nuclear armament of the West German army in April, 1957 (Renn, 2005). "It is signed by eighteen of Germany's most prominent atomic scientists, including four Nobel laureates. The signatories emphasize their unwillingness to participate in the production, testing, or use of atomic weapons” (Renn, 2005).

\section{Human Rights Violation}

This is another issue that divides the world into pro and anti-America. America and her western allies have carved a niche for themselves as global promoter and defender of Human rights. This has, at one time or the other, brought her into confrontation with Russia and China. The case of Russia was highlighted recently by Senator John McCain in his opinion piece on Russia Pravda website while that of China is represented here by Tiananmen Square massacre of protesting University students in China in 1989. Recently, US, as the global protector of Human right were exposed by an American citizen, Edward Snowden, as the greater violator of Human rights, nationally, internationally and, in fact, globally.

It led to Edward Snowden odyssey, first to Hong Kong, to China and lately to Russia with huge amount of US government top classified documents regarding her spying operations on domestic and foreign internet traffic, email and phone use (Snowden, 2013). The rate at which nations, particularly those of South America, were falling over one another in order to grant Snowden asylum show the enthusiasms of how these nations felt about the global monster being humiliated by her own citizen. For the first time, it was also an issue that divided her staunch allies too-Britain, France, Germany, Netherlands and indeed most of the western Europe. According to the French interior minister, "If a friendly country—an ally—spies on France or other European countries, that is completely unacceptable" (The Guardian World News, 2013a).

The number of countries that signified intention to grant asylum to Snowden with varying degree of caveat included: Austria, Bolivia, Brazil, China, Cuba, Ecuador, Finland, France, Germany, Iceland, India, Italy, Ireland, The Netherlands, Nicaragua, Norway, Poland, Russia, Spain, Switzerland and Venezuala (Fung, 2013). The issue of Snowden had already divided the world before the Syrian Chemical Weapon use in her internal conflict cropped up. Bolivian President who was traveling to somewhere and had to pass through the airspace of France and Portugal was denied landing for refuel by these two western allies of US (Pearson, Smith, \& Mullen, 2013). If this were to be an emergence case it would have led to catastrophe. Before this, Snowden's American passport had been withdrawn and left stateless. All these are nothing other than Human right violation by US government.

Speaking the minds of most aggrieved nations whom US has insulted by her spying activities, Brazilian President, Dilma Rousseff, attacked US's espionages by accusing the National Security Agency, NSA, of "violating international law by its indiscriminate collection of personal information of Brazilian citizens and economic espionage targeted on the country's strategic industries". She had earlier, in protest, put off a planned visit to Washington, after NSA documents leaked by Snowden revealed that the US electronic eavesdropping had monitored the Brazilian president's phone calls and spied on the state oil corporation, Petrobras (The Guardian, 2013b).

External protest against US is one thing, internal protests by US citizens are another. Some US citizens protest against their home country militarily, while others do so peacefully but no less deadly. Those engaged in military protest included Anwar al-Awlaki who died in Yemen in 2011. He had been accused of involvement in plots to blow up planes over US soil. He was also chief external operator for al-Qaida in the Arabian Peninsula (Aqap) (The Guardian World News, 2013b). He was deliberately killed by drone attack in Yemen. Other US citizens killed by drone attacks included sixteen year old son of Rahman Anwar al-Awlaki's, Samir Khan and Jude Kenan; although these ones were not specifically targeted. Not less than five Somalia-Americans as well as 
a British woman, married to a deceased terrorist, also took part in therecent Kenya attack.

\subsection{Africa's Rights}

Africa's right as a collection of sovereign nations is under siege of unipolar world and it (Africa) is leading the way aggrieved members of global community could make their protests strongly felt in US in particular and within her allies in general. The global protest of US electronic surveillance activities against individuals, agencies, corporations, governments, and the continents, peaked in Africa and so was counter reaction from Africa. Protests in Africa are not about nuclear power proliferation or Chemical and Biological weapons proliferation. It is not even about protection of global Human right sparse. It is about injustices that have potentials towards Africa thinking of acquiring Nuclear, Chemical or Biological weapons of their own.

It started with Gambia withdrawing her Commonwealth membership over accusation by President YahyaJammeh that the United Kingdom was backing his political opposition ahead of election. "Earlier this year, a Foreign office report singled out the Gambia for its human rights record, citing the cases of unlawful detentions, illegal closure of newspapers and discrimination against minority groups” (BBC News, 2013g).

The Ivory Coast case is the second issue. Following the disputed general elections in 2010 in which Unipolar world intervened to forcefully remove President Gbagbo from office when he refused to accept defeat that led to carnage of 3000 people, the President and his wife were charged with crime against humanity and were to be tried at ICC. While the former President is awaiting trial in The Hague, a warrant was issued for transfer of his (Gbagbo's) wife, Simone, to The Hague for trial. She was accused of murder and rape. Swiftly, "Ivory Coast ministers voted to dismiss the ICC's arrest warrant” (BBC News, 2013h). Lawmakers also shortly followed suit by deciding to file a "motion to dismiss" the ICC's warrant issued in February 2012.

The Ivorian executive later issued a statement stating that "the Cabinet aims to have Mrs Gbagbo brought to trial by Ivorian courts, whose good reputation has been restored and which can hold a fair trial that will guarantee the rights of the defense” (BBC News, 2013h). If Gbagbo's wife is transferred to Hague, She would be the first former First Lady in the world to be so humiliated.

There are also cases of Libya concerning Gaddafi's son, Saif al-Islam Gaddafi, former intelligence officer under Gaddafi rule, Abdullah al-Senussi and the recently kidnapped alleged al-Qaida leader, Nazih Abdul-Hamed al-Ruqai, known as, by his alias, Abu Anas al-Liby. All of them are wanted by ICC to be tried at Hague for crime against humanity but Libyans and militia men in particular, are insisting the trial must take place in Libya. Libya's interim government demanded an explanation from Washington for what it called the "the kidnapping" of a Libya suspect. In the capital, Libyan civilians and political officials also reacted with surpriseand confusion (Gall, Kirkpatrick, Kulish, \& Schitt, 2013; The Guardian World News, 2013c; BBC News, 2013i).

Realizing that Africa is becoming the testing ground or notorious for anything negative, African Union is, first, protesting the trial of both President Kenyatta of Kenya and his Deputy, William Ruto, accused by monstrous US and her octopus western allies of committing crime against humanity (BBC News, 2013j). It (Africa Union) is accusing International Criminal Court, ICC, of "hunting" African leaders, (sitting leaders for that matter) and ignoring atrocities elsewhere. While the trial of Ruto is currently going on in Hague, that of President Kenyatta was expected to commence in November last year (2013). Earlier, Kenya's parliament had voted to leave (ICC). It followed this up with massive campaign for support across Africa. Eventually, a singed letter by 34 out of 54 African leaders was dispatched to ICC, saying Mr Ruto's presence in The Hague will disadvantage Kenya. Extraordinary summit of this agenda was held in the Ethiopian capital, Addis Ababa, on 13 October (BBC News, 2013j).

Secondly, Africa is the first continent where a former head of state of a country, Charles Taylor, would face judgment in an international court on war crime, since judges in Nuremberg convicted Karl Dontiz, an admiral who led Nazi Germany for a brief period following Adolf Hitler’s suicide (The Guardian News, 2013a).

Thirdly, there had been high speculation that the tribunal could overturn Taylor's conviction, following stricter precedents set in the international criminal tribunal for former Yugoslavia president, Milosevic Slobodan, on what constitute "aiding and abetting". Charles Taylor was equally jailed fifty years for "aiding and abetting" Sierra Leone civil war but his own appeal was thrown out on the ground that what constitute "aiding and abetting" in the case of Yugoslavia did not apply to Liberia (The Guardian News, 2013a).

Fourthly and finally, is the issue of caricature African "sovereignties". It is an illusion for any African nation 
today to think it has "sovereignty" in the real sense of the term. The crumbling of sovereignties of African nations, though started during the Cold War when foreign powers sponsored cup d'état in Africa in particular and third world in general, it became brazen after the Cold War (Olasupo, 2009). With the Unipolar world crumbling of sovereignties in Liberia, Ivory Coast, Libya and lately Mali, a powerful signal is sent to Africa that it has formerly entered neo-colonial era politically, economically and socially.

African Union that met in Addis Ababa on the 12 of October last year has begun to react to all these, accusing ICC of treating Africa, especially black Africa, unfairly. Butattempt is already being made to break the solidarity of African Union by ICC decision not to demand Libya's Senusi transfer to Hague to face trial. Reacting to this, Mr. Tedros, who is the current Chairman of AU's Executive Council, said the ICC was "Condescending" towards the continent. According to him, "Far from promoting justice and reconciliation... the court has transformed itself into a political instrument targeting Africa and Africans. This unfair and unjust treatment is totally unacceptable" he said (BBC News, 2013k).

But given the pervasive poor governance performance, corruption and terrorist activities that permeate entire Africa today, can the intervention of unipolar world in African affairs be regarded as ethical? Is it ethically sound for the Unipolar world to remain indifferent to slide to anarchy in Africa when it has wherewithal to checkmate growing incidences of anarchy, terrorism and unbridled corruption in African continent?

African nations are divided on this. While African nations favor move to withdraw from ICC, there is less support for it in West Africa. While Botswana also publicly supports the court, South African National Congress voiced criticism against it. Former UN Secretary-General, Kofi Annan, contributed that withdrawing from the court would be a badge of shame. For Nobel Peace laureate, Archbishop Desmond Tutu, "Those leaders seeking to skirt the court are effectively looking for a license to kill, maim and oppress their own people without consequence. They believe the interests of the people should not stand in the way of their ambitions of wealth and power” (BBC News, 2013l).

On the long run, African Union summit in Ethiopia on the 12 of October, 2013, demanded a deferral of The Hague trial of Kenyan President Uhuru Kenyatta, due to start in November. "It also agreed to a resolution stating no sitting African head of state should appear before an international court”. African leaders have longed complained that the International Criminal Court unfairly target them (African leaders) and causing divide and rule among them at the same time. Currently, both Kenya and Sudanese Presidents are sitting president, more so in the case of Sudan, but only Uhuru Kenyatta was to appear before the court in November (BBC News, 2013k).

\subsection{Religious Rights}

The deadliest protest against unipolar world's Human right campaign comes from Arab world who consider US and her allies to be diametrically opposed to Islamic culture and values. The issues of women's rights with regards to their parity with men, dressing, leadership, democracy and other social activities are opposed to Islamic values and virtues. To add salt to an injury, citizens of US and Britain have brazenly insulted and assaulted Islam holy book-Quran. In March 2011, Terry Jones, a controversial evangelical preacher oversaw the burning of a copy of the Quran in a small Florida church after finding the Muslim holy book "guilty" of crimes. He had earlier planned to ignite a pile of Qurans on the anniversary of September 11, 2001 attacks (AFP, 2011). Again, on September 2013, he planned to burn almost 3000 Qurans but was arrested before he could do so (US News, 2013). This Terry Jones action might be reaction to April 2013 marathon bombing by Dzhokhar Tsarnaev and his elder brother Tamerlan Tsarnaev. The two brothers are Muslim Russian Chechnya schooling in US.

Similarly in Britain, Salman Rushdie, a British-Indian novelist best known for the novel, Midnight's children, wrote another novel in 1988, Satanic verses, which Arab and Islamic world accused him of blasphemy against Islam and on which Iran declare fatwa on him. Again, on 22 May this year, two men hacked a British soldier, Drummer Lee Rigby, to death in a broad daylight on a busy London street. The two men were formally, Christian, Michael Adebolajo, 28 and Michael Adebowale, 22. They later converted to Islam using their Islamic names-Mujahid Abu Hamza for Adebolajo and Ismail Ibn Abdullah for Adebowale (Holden, 2013). Their only reason for Rigby carnage is that "we have killed this man today because Muslims are dying daily by British soldiers” (Martin, Greenhill, Greenwood, \& Cooper, 2013).

Countries such as Pakistan, Yemen, and Afghanistan are hot beds of confrontation against US and her allies over devaluation of Islamic religion. These are countries that have made US and Britain as well as their citizens and interests targets of attack all over the world by bombings and assassinations; through their terror organiza- 
tions such as Taliban, al-Qaida and their various affiliates. Americans have also used the same method (violence), particularly through the use of drone planes (unmanned planes) to get rid of those they consider terrorists.

Some Black African countries with major Islamic population have, however, joined these al-Qaida based countries. Somalia, Mali and Nigeria are typical examples. In Somalia, Somali Islamist group, al-Shabaab, is anal-Qaida affiliate. It ordered a woman stoned to death for sex offence and the victim was indeed stoned to death at Jamama town, $425 \mathrm{~km}$ south of Mogadishu (Olasupo, 2013). It was also said to be responsible for the recent Westgate shopping mall attack in Kenya said to be aimed at foreigners e.g. US and British citizens who patronize it. Not less than 67 people lost their life in it. Less than two weeks after Kenyas attack, US Navy Seal in a pre-dawn, sea-launched counter attacked at al-shabaab leader, named Mukhtar Abu Zubeyr at his seaside villa in the Somali town of Baraawe, south of the capital—Mogadishu (Johnston \&Withnall, 2013).

In Mali, there is a range of Islamist groups who moved into towns including Timbuktu. The Islamists impose their own interpretation of Islamic law, which is anathema to Timbuktu's Sufi inhabitants. "Women were to wear the veil, men to grow beards, and the two were not to associate unless they were married. Those who violated it were whipped in public or locked up in crowded cells” (The Guardian World News, 2013d).

Islamist group in the northern part of Nigeria had a mission of, according to CNN, creating Islamic state. It has identified western education as main enemy of Islamic religion hence adopting the name "Boko Haram" meaning, in Hausa language, "Western Education is forbidden" (Editorial, 2013). To bring this to bear, it recently embarked on attack of schools that are of western traditions. As recently as September 29 2013, "innocent students of the college of Agriculture, Gujba, Yobe State, were woken from their sleep, assembled in groups and then cut down in a barrage of bullets" killing 41 of them. Last year, in Mubi, Adamawa State, over 30 students were killed. Additional more than 40 other students were killed in the town of Mamudo, Yobe State.

Thus, from Somalia to Mali and to Nigeria, the missions of the Islamists insurgents are to enthrone theocratic States based on Islam like Iran, Tunisia, Libya and Egypt. The Central Africa Republic is the latest in the process of doing this. The country has been in turmoil since Muslim Seleka rebels ousted President Francois Bozize in the predominantly Christian country in March this year (The Guardian World News, 2013c). But the events in Syria and Mali have greatly overshadowed this. The violence, apart from murder, rape and burning of houses, has driven more than 440,000 people from their homes. These have ignited reprisal from the Christian militias and gradually leading to religious war. Locales in Bangui have begun to protest calling on France to intervene: "President Hollande we want your help" (The Guardian World News, 2013d).

However, apart from External discomfort of US, her allies, and their responses, there are internal resistances to all these as well. Externally, the only black African country, Somalia that has been graded as terrorist has come under barrage of drone attacks. She has received not less than nine drone visits (The Guardian World News, 2013e). Nigeria is the next country in black Africa to be upgraded as terrorist country because of the ravaging and carnage activities of Boko Haram (which in English means: Western education is evil). But they use western weapons to fight, western medicine to treat their wounded colleagues at battle front, western means of communications to link themselves up, western means of transportation to arrive at their arena of attack etc. Aren't these part of western education too?

It was recently reported that US Congress was about conducting hearing on Boko Haram. To that end, a delegation of the US Congress Committee on African Affairs came to Nigeria recently and met with the President of Nigerian Christian Association, Pastor Ayo Oritseja for, in Abuja (Ayansina, 2013). On the 13 of November, US designated Nigeria's Boko Haram and Ansaru militant groups as foreign terrorist organizations. "The State department described the move as "an important" step to help Nigeria root out violent extremisms” (BBC News, 2013m).

Women in Saudi Arabia have also begun to fight their own causes against series of encumbrances to their freedom. While those encumbrances prescribed by the holy books (e.g. dressing, leadership and associational codes) were understandable they are yet to come to terms with those that are modern and have nothing to do with religion at all. Against proscription of female drivers in Saudi Arabia women are taking part in mass driving protestagainst government authorities (Usher, 2013). To date there have been three such mass female drivers protests-1990, 2011 and today 26/10/2013. "Punishment for deviance protest included arrest and loss of jobs as it was in the case of 1990. Earlier, about 17,000 Saudi people signed a petition calling either for women to be allowed to drive or for an explanation of why the prohibition should remain in force” (Usher, 2013).

In Egypt, Islamist party that came to power a year ago has crumbled; not democratically and not peacefully 
but by bloody military intervention. This led to a huge debate in US and within her allies whether the military intervention was a coup or not. It was recently decided that it was a coup and have therefore begun withdrawal of military aides from Egypt. The Egyptian military, after unconstitutional removal of the Islamist government of President Morsi, installed an unelected civilian president that pander to it. In Libya, the weak Islamist government is still struggling to tame rival militia who recently kidnapped the Prime Minister of the country; Ali Zeidan. Tunisia was however civil in her own approach to removing Islamic government peacefully and democratically through negotiation with secular opponents (Markey \& Amara, 2013).

On the issue of religion, it is interesting to note that neither US nor Russia is making religion a global rivalry. The two super powers, while recognizing religions as integral part of the States, felt they (religions) are expected to be subordinated to the supremacy of the States. They thus found unity in what should be the role of religions in global politics. The two super powers and their allies only clash with any religion that attempt to rival States' supremacy. Otherwise, religion could have been another source of global nuclear or chemical weapon war. Examples from Russia and China would suffice here.

Russia has millions of Muslims; so are Chechnya, Azerbaijjann and State of Georgia (Online, 2013). In the era of Russian communism "all religious practices of all religions including Islam were totally banned. Several generations of Muslims were banned to learn anything about their religions". In fact, "Masjids were locked and religious schools were locked up". After the demise of the Soviet Union, "several Muslim states west of Afghanistan and north of Iran became independent; Islam started reviving in those Muslim states. Masjids are now open and children are being taught practices of Islam and how to read Quran (Online, 2013).

President Putin is said to have claimed that Islam is an inseparable part of Russia, tipping a nod to his Eurasian ambitions but has come out in opposition to Hijabs in schools suggesting that Russia should follow France's lead and resist Islamization of public spaces. Like China, "Russia keeps a tight grip on its Muslim leaders, as it does on the leaders of all religions, who ultimately answer to the authorities. Fundamentalism of a Chinese Muslim led to this. The said Chinese Muslim reportedly burned a Chinese flag (Greenfield, 2013). "The Chinese authorities responded quickly and decisively by issuing a circulation decreeing that Chinese flags be hung at mosques and that the flags be protected by the mosque imams tied to the Communist part. As mandated in the circulars, flagpoles were erected at all mosques and flags were hung” (Greenfield, 2013). Not only that, Chinese authorities prohibited "youth under 18 years old, women, and Muslim Uyghurs who are Communist Party members and civil servant from going to mosque". The clear message being put across in China is that "mixture of mosque and state" is prohibited and that government officials and party members should keep out of mosque. Borrowing from this, official Muslim leaders in Russia can call for terrorism in the West, but never inside Russia. And what they can and can't say is closely monitored and controlled by the authorities” (see Table 3).

This is however no longer the case. Russian Muslims are no longer calling for terrorism in the West but in the Russia itself. And so is Russian government also trying to respond through drone attack inside rather than outside Russia. A woman, 30-year old Dagestan native, Naida Akiyalova, believed to be a partner of an Islamic militant, blew up herself in a bus in southern city of Volgorad, killing at least six people (BBC News, 2013n). Like the Taliban and al-Qaida, the US and her allies are combating in the West, terrorists in Russia are mainly women known as "black widows" and are often "related to Islamic militants and carry out attacks to avenge their deaths". They have a history of nearly a decade behind them. In 2010, they struck at two underground railway stations in Moscow, killing more than 35 people. They were also believed to be responsible for explosion on two passenger jets at a Moscow airport in 2004 that killed 90 people (BBC News, 2013n).

Like US, Russia is also considering the use of drones to combat this all women terrorists "black widows". To this extent, Russia has ordered for Israeli made unmanned aerial vehicles at the cost of $\$ 400$ million. This has brought improvement to Israelis-Russian relation plummeted before (Fater, 2013).

The table above shows absence of state religion for the most powerful nuclear power nations in the world: USA, Russia, China and France. Though Germany is not a nuclear power nation, she has been currently under nuclear protection of her allies (not out of incompetence but sort of punishment for her role in the first and second World Wars. She does not also have state religion. Another observation here is lack of space for black African Traditional Religion (ATR) in the table. The leaders of African Traditional Religion (ATR) are not lying low over this. In countries where they (practitioner of ATR) are predominant like Benin Republic and Equatorial Guinea, foreign religions are given effective challenge not only in political and economic spaces but also in socials as well (Olasupo, 2013).

African Traditional religionists and their supporters have also been persecuting followers of foreign religions 
Table 3. State or established religion.

\begin{tabular}{cccc}
\hline S/NO & RELIGION & NUMBER OF COUNTRIES & COUNTRIES \\
1. & 25 & $\begin{array}{c}\text { Afghanistan, Algeria Bahrain, Bangladesh, The Comoros, } \\
\text { Egypt, Iran, Iraq, Kuwait, Malaysia, the Maldives, Mauritania, } \\
\text { Mauritius, Morocco, Oman Pakistan, Qatar, Saudi Arabia, } \\
\text { Somalia, Sudan, Emirates, Yemen Republic. }\end{array}$ \\
2. & Islam & 11 & $\begin{array}{c}\text { Argentina, Colombia*, Costa Rican Dominican Republic, Haiti, } \\
\text { Panama*, Paraguay +, Peru, Seychelles*, Venezuela* }\end{array}$ \\
3. & Evangelical Lutheran Church & 4 & Denmark, Iceland, Norway, Sweden \\
4. & Buddhish & 3 & Bhutan, Cambodia (Kampuchea), Thailand \\
5. & Greek Orthodox Church & 1 & Greece \\
6. & Judaism & 1 & Israel \\
7. & Hinduism & 1 & Nepal \\
8. & Church ofEngland & 1 & United Kingdom \\
9. & Presbyte-rianism & 1 & United Kingdom (Scotland) \\
10. & Pancasila & + Indonesia +
\end{tabular}

*Quasi-state religion. +Roman Catholicism is the official religion, although the constitution guarantees religious freedom. + A national secular state ideology, stressing unity and social justice, which is a compulsory belief for all social organizations. Source: J. Denis Derbyshire and Ian. Derbyshire, (1991) Spotlight on world Political System, Edinburgh: W \& R Chambers Ltd. P. 27. See also Olasupo (2013) "The Role of Arabian and Western Civilization in the Extinction of African Traditional Religion: The case studies of Senegal, South Africa and Nigeria” in International Journal of Sustainable Development Canada: International Development Agency. Forthcoming.

in the last forty years. It climaxed in detaining a Catholic priest in1976 for being subversive of the state. Not even the visit of the Pope to the country in 1982 was able to set him free (Olasupo, 2013). The ascension into power of a sympathizer of African Traditional Religion, Francisco Macias, who was baptized a Catholic, in Equatorial Guinea, made life uncomfortable for the Christians who constitute $80 \%$ of the country's population. On getting to power, two bishops, one African and the other Spanish, were sent into exile in 1974 (Olasupo, 2013). He followed this up in 1976 with the expulsion of a large number of missionaries and other foreign religious organizations. In 1978, Francisco Macias who proclaimed Equatorial Guinea as first African atheist state banned Catholic and Protestant communities. Until he was over thrown, not less than six Spanish priests were held in prison (Olasupo, 2013). It is important to note here that rather than genuine mission of promoting African Traditional Religion, the fear of the Church, seen locally as a power base that was antagonistic to Francisco Macias, was responsible for his renunciation of Christianity and promotion of ATR.

\subsection{Gay Rights}

Same-sex marriage is another divisive issue that polarized the world and its two major religions. As a weapon of mass destruction, it was said to be responsible for the spread of aids pandemic that ravaged the world more than two decades ago. No religion actually supports this but US and her allies are championing this cause all the same and, in fact, compelling African nations to do so. Meanwhile, not less than fourteen western nations have allowed same-sex marriage: Netherlands (2001), Belgium (2003), Spain (2005), Canada (2005), Norway (2009), Sweden (2009), Portugal (2010), Iceland (2010), Denmark (1989), New Zealand (2013), France (2013) (Hindustan time, 2013); In Britain (2013), Northern Ireland (2013) In US (2003), but not every state in the US has done so. Those states that have approved same-sex marriage include Massachusetts, California, Connecticut, Delaware, Iowa, Maine, Maryland, Minnesota, New Hampshire, New York, Rhode Island, Vermont and Washington District of Columbia and lately New Jersey (New Research, 2013). Some Latin Americans like Argentina, Brazil, Uruguay and Portugal have also followed suit. In Africa, only South Africa has become same-sex marriage country.

Here again US and Russia are poles apart. Russia had issued "nationwide Article 6.13.1 law on restricting the communication of homosexual contents to minor" (Averko, 2013). Although the Russian government maintains that the law's intention is not meant to encourage discrimination against the Lesbians, gay, bisexual and trans- 
gender (LGBT), it has faced opposition from LGBT activists. Critics of the Article 6.13.1says the broadly wording of the law serves to encourage rather than discourage discrimination. They, LGBT, have gotten support from western countries that see Russia as a largely socially conservative with regards to the LGBT. Against 2014 Sochi Winter Olympics coming up in Russia, several western media houses have been calling on the US to wield her big stick against Russia. The big stick here is NBC, the television network with Olympic broadcasting rights in the United States. This is suggested to be used to spend time on covering the opposition to the law rather than the Sochi Olympics game.

\subsection{War Rights}

Under civil war, what rights do the children in particular and the civilian populations in general have, with regards to food and medication. US is lately raising the issue to the global level. Lack of food supply, hunger and medication for children and the civilian population in general, during civil war, is being raised to the status of weapon of mass destruction by US and her allies. The US recently urged "the Syrian government to allow immediate aid convoys to starving civilians cut off in rebel-held suburbs of Damascus” (BBC News, 2013n). According to her, (US), months-long siege left many people in desperate need of food, water and medicine. It also cited "unprecedented reports" of children dying of malnutrition. This is seen as another weapon of mass destruction; more so that "The Syrian army has warned the rebel-held areas must surrender or starve" (BBC News, 2013n). The situation has gotten to a critical stage where a Muslim Cleric issued a religious ruling allowing people to eat cats, dogs and donkeys just to survive. What brought Nigeria civil war to a quick end in 1970 was the employment of method of starvation; though painful, it led to quick resolution of the conflict.

On the issue of starvation as weapon of mass destruction, no reaction has yet emanated from Russia, but US has not also crossed, for Russia, the "red line"-military intervention in the Syrian civil war. If America chooses to, then armed struggle between the two may ensue, for, it is part of UN resolution on Syria that should there be need for US to intervene military in the Syrian question, approval must be obtained from UN.

\section{Observations}

Three issues capable of igniting nuclear and chemical wars in the world have been examined in the paper. While US is the undisputed doyen of all the three, the world is realizing that she (US) is becoming dictatorial and despotic. And therefore there is need to break her monopoly. Russia ought to have been doing this more than two decades ago but it was just emerging ideologically, militarily and economically from the collapsed Soviet Union and her communist ideology to embrace capitalism which it needed time to master. Potentially therefore, she is better positioned to do this, and has done so recently having come of age. America was effectively checkmated in Syria by Russia because of abuse of power and mandate which UN gave her in the case of Libya in 2011. The UN mandate for US did not include regime change much less that of murdering the then head of State of Libya, Moamar Gadhafi. Syria's case thus became US's comeuppance. Russia, supported by her allies, denied US the use of force before, during and even after the destruction of Syria's stockpile of chemical weapons. Even if Syria violates UN resolution on the declaration and destruction of her chemical weapon, US, under the UN resolutions regarding Syria, should not unilaterally embark on application of force. This would be the first universal compromise to whittle down the power of US and her grumbling allies; particularly, Germany, France and Spain.

Economically, again, US is found to be the power house of the world economy. After almost half a century of ideological rivalry between Capitalism and Communism, Capitalism humbled communism with the collapse of Soviet Union in 1990. But an important ally of Russia has rising to fill in the gap. China today is US largest creditor. According to Mr Zhu, a high ranking Chinese official, China and US are "inseparable". Beijing is a huge investor in US Treasury bonds" (BBC News, 20130) China used this vantage position to warn US over the recent government shutdown by telling "US to avoid debt crisis for the sake of global economy", warning that "Washington must agree a deal to raise its borrowing limit by 17 October, or risk not being able to pay its bills" (BBC News, 20130).

On Human rights enforcement by unipolar world and, using Africa as the testing ground, Africa as a continent has met in Addis Ababa on the $12^{\text {th }}$ of August last year to affect Africa's withdrawal from international bodies such as UNO and the Commonwealth. Here, Africa is also setting precedent for other continents in the universe. It is to be a peaceful, non-violent protest and the first time a whole continent would unite against world powers. 
In this, Africa has gotten support of three other continents: South America led by Brazil, Europe by Germany and Asia by Indonesia. Above all, Germany and Brazil are dragging UN into this global outrage by urging a UN General Assembly resolution. This "raft resolution which does not name individual countries, will be debated by a General Assembly committee focusing on human right”.

The draft calls on the UN members to declare that it is "deeply concerned at human rights violations and abuse that may result from the conduct of any surveillance of communication" (BBC News, 2013p). This includes "extraterritorial surveillance of communications, their interception, as well as the collection of personal data, in particular, massive surveillance interception and data collection". The resolution, which was expected to be voted last November, calls on all countries to protect the right to privacy guaranteed under international law. The global allegation against US is that "US have been eavesdropping on foreign leaders, including Brazilian President Dilma Rousseff and German Chancellor Angela Merkel” (BBC News, 2013p).

The actions of North Korea, Syria and Edward Snowden affirm Russia as capable of providing balance of power against US. When North Korea threatened nuclear war against South Korea in early April last year, it was China US and her allies looked up to, to calm down North Korea and she (China, a major ally of Russia) did. It was Russia that pressurized Syria to surrender her chemical weapons for verification and destruction before she could agree to do so. When Edward Snowden had problem with his home country (US), the only places he ran to were first, China and later, Russia that eventually accorded him temporary asylum. All these point to Russia and her powerful ally, China, as effective rival powers to US and her allies, to whom weaker nations could look up to, to call off US bullies.

Finally, religion as potential issue that could ignite nuclear war is being tamed by super powers, while worldwide efforts are being made to prevent nuclear rivalry in the Middle East, the originators of the two most powerful religions in the world-Islam and Christianity. Already, world nuclear powers USA, Russia and China have separated religion and subjugated it to the state. They expect other states in the world to follow suit by persuasion rather than application of force.

\section{Conclusion}

With the compromise reached in the case of Syria, between US and Russia in particular, and UN security council in general, with regards to chemical weapons, the world is inching towards world unification and "government to control atomic bomb", which Albert Einstein envisioned and predicted more than half a century ago (Hawking, 1999). But similar compromise needs to be reached on other flashpoints of the world having nuclear power rivalry - North-South Korea, Israel-Iran and India-Pakistan.

Meanwhile, infrastructures towards World government are already in place: Parliament (UN General Assembly) in New York, Judiciary (International Criminal Court) in The Hague, Interpol (international police). Militarily, North Atlantic Treaty Organization (NATO) and Warsaw Pact need to be fused into a world army. After this, arrangements could then be put in place on how World President could emerge based on two party systems represented by USA and Russia. Of course, there could be other minor parties like Non-aligned nations and Commonwealth of nations etc., these two will be the major ones.

There is a significant and developing idea here. International non-governmental organizations are beginning to tame growing powers of these two super powers. US and Russia are being watched, controlled and blackmailed if they fail to comply with any international treaty on the control of any weapon of mass destruction. First is the Nuclear Information Service (NIS), an organization for the control of nuclear proliferation. It showed, through information obtained under Freedom of Information Act, that US and USSR nearly plunged the world into accidental nuclear war. Second, Organization for the Prohibition of Chemical War (OPCW) recently rebuked the two superpowers for non-compliance with Chemical Weapon destruction Treaty entered into in 1972. Thirdly, Amnesty international as well as other international Human rights organizations called the super powers to order when abusing human right freedom. They recently called for prosecution of US officials responsible for the secret CIA drone campaign against suspected terrorists in Pakistan and Yemen. They (US and Russia) are often accused of "clear violation of international humanitarian laws" such as the killing of 68-year-old woman called MamanaBibi who was killed by missile fired from drone while she was picking okra outside her home with her grandchildren nearby. A second strike minutes later injured family members tendering her (Guardian News, 2013a). These show that the super powers are also not beyond reproach.

Meanwhile, a zone of the world that is neither US nor Russia and located at the middle of the Earth would 
have to be created and infrastructures listed above moved there. At this point, only US, Russia and their allies may retain their nuclear arsenal as a balance of terror here on Earth and as planetary rivalry: mankind is already in Mars exploring its challenges and Rockets of various types are equally in space to rival celestial bodies such as Comets, Meteoroids and Asteroids. (After the incident of Russia meteorite that injured more than 1000 people, destroyed over 7200 buildings, nuclear scientist predicted that nuclear weapon could be used to fight these terrestrial bodies before they reach the Earth's atmospheres

Although this is said to be century affair, preparation towards combating can be made far ahead of similar occurrence. The last time such happened was in 1908 in Siberia. But the recent one in Russia, according to National Aeronautic Space Administration (NASA), "was a space rock about 50 feet in diameter. They said the resulting explosion was equivalent to detonating about 300 kilotons TNT—making it roughly 20 times more powerful than atomic bomb dropped on Hiroshima, although the bomb was detonated near the earth surface" (The Boston Globe, 2013).

This will surely require synergy of effort between these rival super powers. Currently, there is intense rivalry between US and Russia on one hand and their allies on the other. Starting from 1960, USSR (now Russia) was the first country to attempt reaching Mars and actually reaching there but unable to land successfully on more than eleven occasions. USA started in 1980 and has made eight successful landing on the Mars (Kluger, 2012). One of the allies of US, Europe, has also successfully landed spacecraft on the Mars and a third one-India —is about to with the successfully launching of Mars spacecraft on the $5^{\text {th }}$ of November, 2013. An ally of Russia, China, is just potentially warming up. It is already being speculated that with this successful launching attempt, space race has commenced between India and China, the two most populous and nuclear states in Asia (BBC News, 2013q). Thus, in the same way that we have five nuclear club states (US, Russia, Britain, France and China) so are we beginning to have five spaces club (USA, Russia, Europe, India and, any moment from now, China).

These are just military dimensions of nuclear power; there is also a peaceful dimension of it as well. Recently, four top environmentalist scientists raised the stakes in their fight to reverse climate change and save the planet. These climate and energy scientists: James Hansen, Ken Caldeira, Kerry Emanuel and Tom Wigley released an open letter calling on world leaders to support development of safer nuclear power system, which they believed is the only way to reverse the looming threat of climate change which they blamed on fossil fuels (Patterson, 2013). Thus, long after his demise, Albert Einstein ideas find new role for our nuclear weapons against terrestrial challenges and the destructive climate change. Albert Einstein comes to life again!

Unification of the world religions, particularly the most important and pervasive ones-Islam and Christianity-will come about at the nick of time and Science and technology are going to be the means through which this would be realized. The Pope already represents the Christian world while King Fad of Saudi Arabia, the custodian of the Muslim holy land, Makah, represents the Islamic world. Both of them are already allies of unipolar world. Both religions do not deny the potency of science and religion but are, in fact, dependent on it: Medicine, Aircrafts, Motor cars, Telephones, Television, Satellites etc. are not manners from heaven; rationality and rigorous scientific and technological research produced them not passion and emotions that are the hall and trademarks of religions.

When all of these shall have been realized, Albert Einstein would have truly become "THE CHIEF ENGINEER OF THE UNIVERSE” (Renn, 2005).

\section{References}

AFP (2011). Quran Burnt in Florida Church. 21 March.

AFP (2013). Same-Sex Marriage Gaining Acceptance, 14 Countries Where It’s Legalized. Hindustan Times, 17 October.

Averko, M. (2013). Gay Rights in Russia and the 2014 Sochi Winter Olympics. Global Research, 16 September.

Ayansina, C. (2013). US Congress to Conduct Hearing on Boko Haram: FG to Create Compensation Fund for Victims. In The Vanguard, 25 September, 8.

BBC News (2013a). India PM Singh in “Terror” Warning to Pakistan ahead of Talks. Online, 29 September, 2013. Last updated at 02:54.

BBC News (2013b). Iran’s Rouhani Claims Full Authority to Seek Nuclear Deal. Online, 27 September. Last updated at 20:21

BBC News (2013c). South Korea Display Cruise Missiles at Military Parade. 1 October, 2013.

BBC News (2013d). US sack Nuclear Missiles General Michael Carey. Online, 11 October. 
BBC News (2013e). StanislavPetrov: The Man Who May Have Saved the World. 26 September 2013

BBC News (2013f). John McCain Takes Aim at Putin in Russia Press. 19 September 2013. Last updated at 12:16

BBC News (2013g). The Gambia to Withdraw from Commonwealth. Online. 3 October.

BBC News (2013h). Ivory Coast Dismisses ICC Warrant for Simone Gbgbo. 20 September.

BBC News (2013i). Gaddafi-Era Spy Chief al-Senussi to be Tried in Libya. 11 October 2013.

BBC News (2013j). African Union Summit on ICC Pullout over Ruto Trial. 20 September, Online.

BBC News (2013k). African Union Urges ICC to Defer Uhuru Kenyatta’s Case. 12 October.

BBC News (2013l). African Union Condemns Unfair ICC. Online. 11 October, 2013.

BBC News (2013m). US Names Nigeria’s Boko Haram and Ansaru “Terrorist”. November 13.

BBC News (2013n). Russia Bus Bomb: Volgorad Blast Kills Six. 21 October.

BBC News (2013o). Syria Must Allow Aid Convoys to Starving Civilians, Says US. In bbc.co.uk navigation Menu. 19 October.

BBC News (2013p). China Tells US to Avoid Debt Crisis for Sake of Global Economy. 7 October 2013). Online.

BBC News (2013q). India Launches Spacecraft to Mars. 5 November.

Browne, B. (2013a). G-20 Summit: More Questions than Answers: Those Who March Swiftly to War Are Those Who Never Have to Fight. The Nation on Sunday, September, 65.

Browne, B. (2013b). Stumbling out of War? Syria, the Media and Lessons Learned: A Mistake Timely Made Can often Be More Profitable than a Perfect Answer Tardily Had. In The Nation on Sunday, 13 September, 12.

Editorial (2013). Protect Schools from Terrorists. Vanguard, 14 October. Online.

Fani-Kayode, F. (2013). America’s Blood Lust and the Bombing of Syria. The Nation, 8 September. 66.

Fater, Y. (2013). Israel Signs $\$ 400$ Million Deal to Sell Spy Drones to Russia. In Israel News, 14 October.

Fung, B. (2013). The Complete List of Countries Where Edward Snowden Wants Asylum. In National Journal Defense, 26 June. Online.

Gall, C., Kirkpatrick, D. D., Kulish, N., \& Schmitt, E. (2013). Libya Demands Explanation after US Raid Captures Terror Suspect. http://boston.com/.

Golden, F. (1999). Albert Einstein: He Was the Pre-Eminent Scientist in a Century Dominated by Science. The Touchstone of the Era-The Bomb, the Big Bang Quantum Physics and Electronics-All Bear His Imprint. Person of the Century Time, 31 December, 37.

Greenfield, D. (2013). How Russia and China Deal with Islam. Frontpage Mag, 23 March.

Greenslade, R. (2013). Putin Chooses New York Times to Address the American People. in the Guardian. Online.

Guardian News (2013a). Amnesty Says US Officials Should Face War Crimes Charges over Drone Strikes. 23 October.

Guardian World News (2013a). How a War Game Brought the World to the Brink of Nuclear Disaster. 3 Novermber.

Hawking, S. (1999). A Brief History of Relativity: What Is It? How Does It Work? Why Does It Change Everything? An Easy Primer by the World’s Most Famous Living Physicist. Person of the Century Time, 31 December, 32.

Holden, M. (2013). Two Men Plead not Guilty to Killing British Soldiers on London Street. 27 September. Online

Johnston, I., \& Withnall, A. (2013). US Navy Seal Team Fails in Attempt to Kill Al-Shabaab Leader in Somalia Raid Following Nairobi Mall Attack. The Independent, 6 October. Online.

Karimi, F. (2013). 20 Questions about the Iran Nuclear Deal: What It Says, What's at Stake, What's Next. CNN, Online.

Kate, D. T., \& Yoon, S. (2013). Kerry Hails China in Urging North Korea Programs. Bloomberg, 1 July, 12:00 PM EDT.

Kluger, J. (2012). MARS: What We Can Learn from a Robot 248 Million km Away. Time, 20 August. 8.

Magidor, M. (2005). President of the Hebrew University of Jerusalem. In JurgenRenn (Ed.) Chief Engineer of the Universe: Albert Einstein: Einstein's Life and work in context. Berlin: Weinheim and Max Plank Institute for the history of Science. P13.

Markey, P., \& Amara, T. (2013). Tunisia Islamists in Talks to Relinquish Power. Business Day Live-mobile, 7 October.

Martin, A., Greenhill, S., Greenwood, C., \& Cooper, R. (2013). View Comments. 23 May. Online.

New Research (2013). Gay Marriage around the World. Religion and Public Life Project, 16 July.

Olasupo, F. A. (2009). Africa and the Challenges of Unipolar World: Sovereignty, Civil Society and Women'S Rights as Case Studies”. African Journal of Political Science and International Relations, 3, 320-340. August 2009.

http://www.academicjournals.org/AJPSIR 
Olasupo, F. A. (2013). The Role of Arabian and Western Civilization in Extinction of African Traditional Religion: The Case Studies of Senegal, South Africa and Nigeria. International Journal of Sustainable Development, 5, 19-34. Canada: International Development Agency. http://srn.com/abstract=2333260

Online (2013). Are there Muslims in Russian. In an Online questions and answers.

Patterson, T. (2013). Climate Change Warriors: It's Time to Go Nuclear. In CNN, 3 November.

Pearson, M., Smith, M., \& Mullen, J. (2013). Snowden’s Asylum Options Dwindle. CNN, 2 July. Online

Perlez, J. (2013a). China Bluntly Tells North Korea to Enter Nuclear Talks. 24 May. Online

Perlez, J. (2013b). China Bans Items for Export to North Korea, Fearing Their Use in Weapons. 24 September. Online.

Philippe, P. (1999). Beyond Genius: Patek Philippe’s Legendary Legacy. Person of the Century Time, December 31, P17.

Renn, J. (2005). Einstein and Judaism. In J. Renn (Ed.), Chief Engineer of the Universe: Albert Einstein: Einstein's Life and Work in Context (pp. 146, 203). Berlin: Weinheim and Max Plank Institute for the History of Science.

Renn, J. (2005). The Atomic Bomb. In Renn, J. (Ed.), Chief Engineer of the Universe: Albert Einstein: Einstein's Life and Work in Context (pp. 156, 200). Berlin: Weinheim and Max Plank Institute for the History of Science.

Rosenblatt, R. (1999). The Age of Einstein: He Became, Almost Despite Himself, the Emblem of All That Was New, Original and Unsettling in the Modern Age. The TIME Person of the Century, 31 December, 47.

Snowden, E. (2013). Edward Snowden: ‘The US Government Will Say I Aided Our Enemies’-Video Interview. The Guardian, 8 July. Online.

Starr, B. (2013). Missile Doors Left Open While Air Force Nuclear Officer Slept. CNN Pentagon, 23 October.

The Boston Globe (2013). Russian Meteor a once in a Century Display-Science-The Boston. 15 February.

The Guardian (2013a). US Nearly Detonated Atomic Bomb on Own Soil by Accident in 1961. 21 September.

The Guardian (2013b). Brazilian President: US Surveillance a ‘Breach of International Law’. 24 September.

The Guardian News (2013a). Charles Taylor’s 50-Year Sentence Upheld at War Crimes Tribunal Unsubscribed. Online.

The Guardian World News (2013a). Snowden Leaks: France Summons US Envoy over NSA Surveillance Claim. 21 October.

The Guardian World News (2013b). White House Says Drone Strikes Have Killed Four US Citizens. 23 May. Online

The Guardian World News (2013d). Libya Demands Explanation for 'Kidnapping' of Citizen by US Forces. Sunday, 6 October. Online

The Guardian World News (2013e). France to Boost Troops in Central African Republic as Crisis Deepens. 23 May, Online.

The Guardian World News, (2013c) Global Development: Islamist Insurgency in Mali Casts Long Shadow over Timbuktu. 1 July, Online.

The Times of Israel (2013). Full Text of Netanyahu’s 2013 Speech at the UN General Assembly: Prime Ministers Says the World Must not be Fooled by the New Face of the Iranian Regime.1October, 8:52 pm. Online.

US News (2013). Controversial Pastor Terry Jones Arrested before He Could Burn Qurans 11 September. Online.

Usher, S. (2013). Saudi Government Warns Women over Driving Protest. BBC News, 26 October.

Walsh, N. P., \& Labott, E. (2013). CNN, Security Council OKs Syria Resolution, Warns of Consequences. 9 September.

Wikipedia (2013). List of States with Nuclear Weapons. In Wikipedia, the Free Encyclopedia. Online. 